\title{
Astım Hastalarında Tedavinin Nitrik Oksit ve Asimetrik Dimetil Arginin Düzeylerine Etkisi
}

\section{The Effect of Treatment on Nitric Oxide and Asymmetric Dimethyl Arginine Levels in Asthma Patients}

\author{
Sükeynet Aydın ${ }^{1}$, Cahit Bilgin², Asuman Deveci Özkan*3, Ayşe Erdoğan Çakar ${ }^{4}$, Mehmet Akdoğan ${ }^{5}$, Mehtap \\ Erdoğan 6
}

\author{
${ }^{1}$ Sakarya Üniversitesi, Sağlık Bilimleri Enstitüsü, Tıbbi Biyokimya Anabilim Dalı, Sakarya, Türkiye \\ ${ }^{2}$ Sakarya Üniversitesi, Tıp Fakültesi, Göğüs Hastalıkları Anabilim Dalı, Sakarya, Türkiye \\ ${ }^{3}$ Sakarya Üniversitesi, Tıp Fakültesi, Tıbbi Biyoloji Anabilim Dalı, Sakarya, Türkiye \\ ${ }^{4}$ Yıldız Teknik Üniversitesi, Araştırma Planlama Bölümü, İstanbul, Türkiye \\ ${ }^{5}$ Sakarya Üniversitesi, Tıp Fakültesi, Tıbbi Biyokimya Anabilim Dalı, Sakarya, Türkiye \\ ${ }^{6}$ Sakarya Üniversitesi, Tıp Fakültesi, Anatomi Anabilim Dalı, Sakarya, Türkiye
}

e-mail: sukunetaydin@gmail.com, cahitbilgin@sakarya.edu.tr,deveci@sakarya.edu.tr, ayseerdogan84@gmail.com,makdogan2009@gmail.com,mehtaperdogan@sakarya.edu.tr

ORCID: 0000-0001-8129-5274

ORCID: 0000-0002-9455-1035

ORCID: 0000-0002-3248-4279

ORCID: 0000-0002-5568-3959

ORCID: 0000-0002-0345-8362

ORCID: 0000-0002-5422-5091

*Sorumlu Yazar / Corresponding Author: Sorumlu Yazar: Asuman Deveci Özkan ${ }^{3}$

Gönderim Tarihi / Received: 18.11.2019

Kabul Tarihi / Accepted: 08.04.2020

DOI: $10.34087 /$ cbusbed.648181

\begin{abstract}
Giriş ve Amaç: Asimetrik dimetilarjinin (ADMA) ve nitrik oksit (NO), etkilerini birlikte gösterirler, bu moleküller arasındaki denge hava yolu tonusunun ve fonksiyonunun sıkı düzenlenmesine katkıda bulunmaktadır. Çalışmamızda astım tedavisinin serum ADMA, NO, düzeylerine solunum fonksiyon testlerindeki (SFT) değişimlerine, Total IgE, hemogram düzeylerindeki değişiklikleri belirlemeyi amaçlanmıştır.

Gereç ve Yöntemler: Çalışmamızda astım tanısı konmuş 30 erkek/kadın hasta (40-60 yaş) ve benzer yaş grubunda 24 erkek/kadın kontrol grubu kullanılmıştır. Çalışmada tedavi öncesi ve sonrası hasta ve kontrol gruplarından serum ADMA, NO, Total IgE düzeylerine ELISA yöntemiyle ve hemogram düzeyleri ise otomatik kan sayım cihazında belirlenmiştir.

Bulgular: Astımlı hastaların tedavi öncesi ve tedavi sonrası ADMA ve NO düzeyleri kontrol grubu ile arasında anlamlı fark bulunmuştur $(\mathrm{p}<0,001)$. Astımlı hastaların tedavi öncesi ve tedavi sonrası grupların total IgE düzeyleri kontrol grubu ile arasında fark istatistiksel olarak anlamlı bulunmuştur. ( $\mathrm{p}<0,001)$. Astımlı hastaların tedavi öncesi ve tedavi sonrasi grupların $\% \mathrm{FVC}$ ve $\% \mathrm{PEF}_{25-75 \%}$ düzeyleri kontrol grubu ile arasındaki fark, tedavi öncesi grubun $\% \mathrm{FVC}, \% \mathrm{PEF}_{25-75 \%}$ düzeyleri tedavi sonrası grup arasındaki fark istatistiksel olarak anlamlı bulunmuştur ( $\left.\mathrm{p}<0,001\right)$. Sonuç: Astım hastalarında tedavinin hastalar üzerindeki etkileri bu çalışma ile belirlenmiş ve elde edilen veriler tedavi sonrası astım hastalarında iyileşme gözlenen parametre düzeylerinin astım hastalarında tedaviye yanıtın takibinin belirlenmesinde kullanılabileceği ortaya konmuştur.
\end{abstract}

Anahtar Kelimeler: Astım, ADMA, nitrik oksit, ELISA, Solunum Fonksiyon Testleri.

\section{Abstract}

Objective: Asymmetric dimethyl arginine (ADMA) and nitric oxide (NO) show their effects together and the balance between these molecules contributes to the tight regulation of airway tone and function. In this study, we aimed to determine the changes in serum ADMA, NO, levels of pulmonary function tests (PFT), total IgE and hemogram levels of asthma treatment. 
Materials and Methods: In this study, 30 male / female patients (40-60 years) diagnosed with asthma and 24 male / female control groups of similar age group were used. In the study, serum ADMA, NO, Total IgE levels before and after treatment were determined by ELISA method using commercial kit and hemogram levels were determined by automatic blood counting device.

Results: There was a significant difference between ADMA and NO levels in asthmatic patients before and after treatment $(\mathrm{p}<0.001)$. The difference between total IgE levels of asthmatic patients before and after treatment was found to be statistically significant $(\mathrm{p}<0.001)$. The difference between the FVC\% and PEF25-75\% levels of the pretreatment and post-treatment groups of the asthmatic patients with the control group and the \%FVC and \%PEF25$75 \%$ of the pretreatment group were found to be statistically significant $(\mathrm{p}<0.001)$.

Conclusion: The effects of treatment on asthmatic patients were determined in this study and it was shown that the parameter levels improved in asthmatic patients after treatment can be used to determine the response to treatment in asthmatic patients.

Keywords: Asthma, ADMA, nitric oxide, ELISA, Pulmonary Function Tests.

\section{Giriş}

Astım, tüm dünyada yaklaşık 300 milyon kişiyi etkilediği tahmin edilen ciddi bir halk sağlığı sorunudur [1]. Her yaştan bireyi etkileyebilen, doğru tedavi ile kontrol altına alınabilen, kontrol altına alınamadığında ise günlük aktiviteleri ciddi olarak kısitlayabilen kronik bir hastalıktır [2]. Astım, hava yollarının daralması ile kendini gösterir ve krizler halinde gelir. Astımda kişilerde hava yolu duvarı şiş ve ödemlidir. Bu durum akciğerlerin uyaranlara aşırı duyarlı olmasına neden olur. Toz, duman, koku gibi uyaranlar ile hemen öksürük, nefes darlığı ve göğüste baskı hissi gibi yakınmalar ortaya çıkar. Krizde hava yollarını saran kaslar kasılır, ödem ve şişlik artar, ilerleyen iltihapla birlikte hava yolu duvarı kalınlaşır. Hava yollarındaki salgı bezlerinden kıvamlı bir balgam atılır. Tüm bunlar hava yollarını önemli ölçüde daraltır ve havanın akciğerlere girip çıkması engellenir. $\mathrm{Bu}$ durum, artan öksürük, nefes darlığı, hırıltı, hışıltı ile kendini göstermektedir [3].

Asimetrik dimetilarjinin (ADMA), arjinin amino asitinin translasyon sonrası modifiye olmuş bir formudur. ADMA endojen nitrik oksit sentaz (NOS) inhibitörü olarak nitrik oksit (NO) oluşum hızını düzenlemektedir [4]. NO sadece endotel bağımlı vazodilatasyon değil aynı zamanda damar duvarındaki düz kas proliferasyonu, lümendeki hücre-hücre etkileşimleri, platelet adezyon ve agregasyon inhibisyonu ve monosit adezyon inhibisyonu gibi düzenleyici fonksiyonları da olan vasküler dengenin sağlanmasında ve organ kan akımının idamesinde rol alan kilit bir moleküldür [5].

Literatürde ADMA ve astım ile ilgili yapılan çalışmalara bakıldığında, astımlı çocuklarda ADMA seviyesinin kanda [6], balgam örneklerinde [7] ve ekpiryum havasında [8] arttığı gözlenirken, farelerde yapılan çalışmalarda alerjik hava yolu imflamasyonu ve bronş aşırı duyarlılığına sebep olduğu gösterilmiştir [7]. Son zamanlarda ADMA'nın geç başlangıçlı astım ve obezite semptomlarının şiddeti ile de ilişkili olduğu tespit edilmiştir [8]. Holguin ve ark [9]'nın astım hastalarında yaptığı çalışmada periferik plazma örneklerindeki ADMA düzeylerinin solunum fonksiyon parametrelerinin kötüleşmesi ile ilişkili olduğu bildirilmiştir. Havayolu aşırı duyarlılığında ADMA'nın potansiyel rolünü öne çıkaran çalışmalara bakıldığında, hafif eozinofilik astımlı erişkinlerin balgam örneklerinde \% FEV1 değerinde \%20 düşüşe neden olan provokatif

konsantrasyon sonucu bireylerdeki ADMA
düzeylerindeki artış arasında anlamlı bir ilişki gösterilmiştir [10, 11].

Astımlı bireylerde hava yolu obstrüksiyonundan sonra alınan örneklerde ADMA düzeyinde artış gözlenmiştir. Ayrıca astım tedavisinin hastalardaki ADMA ve NO'nun seviyelerine olan etkisi ile ilgili literatürde herhangi bir çalışmaya rastlanmamıştır. $\mathrm{Bu}$ nedenle çalışmamızda astım hastası olmayan kontrol bireyleri ile tedavi öncesi ve tedavi sonrası gruplar oluşturularak, astım da rol oynayan solunum fonksiyon testleri, CAT anket skoru, serum ADMA, NO, total IgE, ve Hemogram değişimleri karşılaştırmalı olarak analiz edilmiş, tedavinin astım hastalarında bu parametreler üzerine olan etkisi değerlendirilerek, bu parametrelerin hastalığın erken teşhisinde moleküler belirteç olarak kullanılabilme potansiyeline ve astım etyopatogenezine 1 şık tutacak veriler elde edilmesi amaçlanmıştır.

\section{Materyal ve Metot}

$\mathrm{Bu}$ çalışma Sakarya Üniversitesi Bilimsel Araştırma Projeleri Komisyonu [BAP-K 2016- 40-01-004 nolu proje) tarafından desteklenmiştir. Katılımcılardan bilgilendirilmiş onam alınmıştır. Ayrıca Tıp Fakültesi Girișimsel Olmayan Araştırmalar Etik Kurulu tarafından Helsinki Deklarasyonu prensiplerine uygun olarak 01.06.2016 tarih 7443/98 sayılı onayı alınarak gerçekleştirilmiştir.

\subsection{Hasta Seçimi}

Sağlık Bakanlığı Sakarya Üniversitesi Eğitim ve Araştırma Hastanesi (SEAH) Göğüs Hastalıkları Polikliniği'ne başvuran GINA'a [12] göre astım tanısı konmuş 30 erkek/kadın hastadan (40-60 yaş) tedavi öncesi ve tedavi sonrası alınan kan örnekleri ile gerçekleştirildi. Kontol grubu olarak ise hasta grubuna benzer yaş grubunda bilinen herhangi bir hastalığ olmayan gönüllü 24 erkek/kadın belirlendi.

\subsection{Kan Örneklerinin Alınması ve Hazırlanması}

Tedavi öncesi ve tedavi sonrası hasta ve kontrol gruplarından aç karnına ADMA, NO ve Total IgE için hastalar oturur pozisyonda iken iki ayrı anti-koagulansız ve antikoagulanlı tüplere kan örnekleri alındı. ADMA ve arjinin örnekleri hemen soğuk zincir kurallarına uyularak soğutmalı santrifüj ile $+40 \mathrm{C}$ de $2000 \mathrm{xg}$ devirde 5 dakika 
santrifüj edildikten sonra serumları ayrıldı. Ayrılan serumlar sülfosalisilik asit ile uygulanan deproteinizasyon işleminden sonra ADMA ve arjinin çalışmaları için ependorf tüplere aktarılıp $-80 \mathrm{oC}$ de çalışma gününe kadar muhafaza edildi. NO örnekleri 2000 xg devirde 5 dakika santrifüj edilerek serum örnekleri $-80 \mathrm{oC}$ de çalışma gününe kadar muhafaza edildi.

\subsection{ADMA Tayini}

Çalışmada ADMA tayini gerçekleştirmek için ELİSA (Enzyme-Linked Immunosorbent Assay) yöntemi kullanılmıştır. Uygulanan işlemler sonucu oluşan renk değişimi $450 \mathrm{~nm}$ 'de elisa reader ile okunmuştur. ADMA stok solüsyonundan $(0,5 \mathrm{mM}) 200 \mu \mathrm{l}$ alındı ve $0,1 \mathrm{M} \mathrm{HCl}$ ile $1000 \mu$ l'ye tamamlanarak (1/5) standart solüsyon hazırlandı. Hazırlanan standart solüsyon $0,1 \mathrm{M} \mathrm{HCl}$ ile seri dilüsyonlara tabi tutularak standart çözeltiler hazırland

Dilüe edilmiş standart solüsyondan $50 \mu \mathrm{l}$ alınarak standart için ayrılmış kuyulara eklendi. Örnekler için ayrılmış kuyulara $40 \mu \mathrm{l}$ örnek ve üzerine $10 \mu \mathrm{l}$ ADMA antikoru eklendi. Kör için ayrılan kuyulara herhangi bir reaktif eklenmedi. Sonrasında standart ve örneklere $50 \mu \mathrm{l}$ Streptavidin-HRP eklendi, çalkalayıcı yardımıyla karıştırıldı ve 60 dakika $37^{\circ} \mathrm{C}^{\prime}$ de inkübe edildi. İnkübasyon sonrasında 30x yıkama solüsyonu ile plate 5 kere yıkandı. Yıkama işlemi tamamlandıktan sonra kör için ayrılmış olan kuyularda dâhil olmak üzere kör, standart ve numunelere $50 \mu 1$ kromojen çözelti A, $50 \mu \mathrm{l}$ kromojen çözelti B eklendi, 10 dakika $37^{\circ} \mathrm{C}$ ' de inkübe edildi. İnkübasyon sonrasında tüm kuyulara $50 \mu \mathrm{l}$ durdurma çözeltisi eklendi, çalkalayıcı yardımıyla karıştırıldı ve 15 dakikalık zaman dilimi içerisinde 450 nm'de köre karşı okudu.

\subsection{NO Tayini}

Çalışmada nitrit/nitrat kolorimetrik ELISA kiti kullanıldı. Analiz sonucunda oluşan renk değişimi 540$550 \mathrm{~nm}$ 'de elisa reader ile okundu. İlk olarak kör olarak belirlenen kuyulara $200 \mu \mathrm{l}$ distile su eklendi. NO ölçümü için nitrat standardı hazırlanarak kullanıldı. Örnekler 1/5 oranında dilüe edilerek toplam hacim $80 \mu \mathrm{l}(16 \mu \mathrm{l}$ serum $+64 \mu 1$ deney çözeltisi) olacak şekilde kuyulara yüklendi. Sonrasında standart ve örneklerin üzerine $10 \mu \mathrm{l}$ nitrat redüktaz ko-faktör karışımı ve $10 \mu \mathrm{l}$ nitrat redüktaz enzimi eklendi. Hazırlanan örnekler plate'in üzeri parafilm ile kapatılarak 1 saat oda sıcaklığında inkübe edildi. Bir saatlik inkübasyon süresi sonunda kör kuyu dışında standart ve örnek kuyularına $50 \mu$ l griess reaktifi 1 ve $50 \mu \mathrm{l}$ griess reaktifi 2 eklendi. Hazırlanan plate oda sıcaklığında karıştırılarak 10 dakika inkübe edildi. İnkübasyon sonunda oluşan renk değişimi $540 \mathrm{~nm}$ 'de okundu.

\subsection{Total IgE ölçüm yöntemi}

Beckman Coulter Immage Immunochemistry Systems analizatöründe (Beckman Coulter Inc, Fullerton, CA.
USA) Beckman Coulter's reagent kiti kullanılarak türbimetrik yöntem ile ölçüldü.

2.6. Hemogram Ölçümü

Coulter Gen-S hematoloji analizatöründe (Beckman Coulter Inc, Fullerton, CA. USA). Coulter scatter pak ve Iyses III dift lytic reaktif kiti kullanılarak hemogram ölçümü yapıldı.

\subsection{Solunum fonksiyon testleri}

Solunum Fonksiyon Testleri Spirolab III spirometri (Spirolab; Medical International Research, Roma, İtalya) tarafından Amerikan Toraks Derneği / Avrupa Solunum Derneği kriterlerine göre yapıldı [13]. Zorlu vital kapasite (FVC), FEV1, FEV1 / FVC oran1, pik ekspiratuar akım (PEF) ve FVC'nin \%25 ila 75'i (\% FEV $25-75 \%$ ) arasında zorunlu ekspiratuar akım kaydedildi.

\subsection{Istatistiksel Analiz}

İstatistiksel değerlendirmeler "SPSS 9.00 for Windows" programı kullanılarak gerçekleştirildi. Gruplar arasındaki anlamlılığı belirlemek için Kruskal-Wallis varyans analiz testi kullanıldı. Grupların ikişerli karşılaştırılması için; normal dağılım gösteren gruplarda Student's t testi, normal dağılım göstermeyen gruplarda ise Mann Whitney U testi kullanıldı. Sonuçlarda $\mathrm{p}<0,05$ anlamlı kabul edilmiştir. Sonuçlar ortalama \pm SD (standart sapma) olarak verildi.

\section{Bulgular ve Tartışma}

Çalışmamızda tedavi öncesi ve tedavi sonrası astımlı hastalar ve kontrol grubuna ait toplam 84 bireyin yaş, ADMA, NO, Total IgE düzeylerinin aritmetik ortalama ve standart sapmaları Tablo 1'de verilmiştir. Kontrol grubu ile tedavi öncesi ve tedavi sonrası ADMA, NO düzeyleri arasında anlamlı fark bulunurken (sırasıyla $\mathrm{p}<0,001, \mathrm{p}<0,05$ ), tedavi öncesi ve sonrası ADMA ve NO düzeylerinde artış görülmekle birlikte bu artış istatistiksel olarak anlamlı bulunmad $1(p>0,05)$. Kontrol grubu ile tedavi öncesi ve tedavi sonrası grupların total IgE düzeyleri arasındaki fark istatistiksel olarak anlamlı bulunurken $(\mathrm{p}<0,001)$, tedavi öncesi ile tedavi sonrasi total IgE düzeylerinde düşüş anlamlı bulunmamıştır $(\mathrm{p}>0,05) \quad$ (Tablo 1). Astım hastalarına uygulanan tedavinin total $\mathrm{IgE}$ düzeyini azaltmış olması, tedavinin total IgE düzeyi üzerinde yeterince etkili olmadığını ortaya koymuştur.

Tedavi öncesi ve tedavi sonrası astımlı hastalar ve kontrol grubuna ait toplam 84 bireyin SFT, \%FVC, FVC (L), \%FEV1, FEV1 (L), (\%) FEV1/FVC, \% PEF25-75\%, PEF25-75\% (L) düzeylerinin aritmetik ortalama ve standart sapmaları Tablo 2'de verilmiştir. Kontrol grubu ile tedavi öncesi grubu \%FVC düzeyleri arasındaki fark anlamlı bulunurken $(\mathrm{p}<0,05)$, tedavi sonrası grubu $\%$ FVC düzeyleri arasındaki fark anlamlı bulunmamıştır $(p>0,05)$. Tedavi öncesi ile tedavi sonrası \%FVC düzeyleri arasındaki fark anlamlı bulunmamıştır $(\mathrm{p}>0,05)$. Kontrol grubu ile tedavi öncesi ve tedavi sonrası FVC düzeyleri arasındaki fark ve tedavi öncesi ile tedavi sonrası FVC düzeyleri arasındaki fark anlamlı 
Tablo 1. Çalışmamızdaki tedavi öncesi ve tedavi sonrası astımlı hastalar ve kontrol grubuna ait ADMA, NO ve Total IgE verileri.

\begin{tabular}{|l|c|c|c|c|}
\hline Gruplar & $\begin{array}{c}\text { YAŞ } \\
(\mathbf{Y} \mathbf{l})\end{array}$ & ADMA (ng/ml) & $\begin{array}{c}\text { NO } \\
(\boldsymbol{\mu M})\end{array}$ & Total IgE (IU/ml) \\
\hline $\begin{array}{l}\text { Kontrol Grubu } \\
(\mathrm{n}=24)\end{array}$ & $44,63 \pm 16,49$ & $39,24 \pm 11,19$ & $12,63 \pm 0,82$ & $20,72 \pm 9,86$ \\
\hline $\begin{array}{l}\text { Tedavi Öncesi } \\
\text { Grubu } \\
(\mathrm{n}=30)\end{array}$ & $51,70 \pm 16,49$ & $30,21 \pm 5,11^{\mathbf{a}}$ & $8,73 \pm 2,94^{\mathbf{a}}$ & $98,76 \pm 41,16^{\mathbf{a}}$ \\
\hline $\begin{array}{l}\text { Tedavi Sonras1 } \\
\text { Grubu } \\
(\mathrm{n}=30)\end{array}$ & $51,70 \pm 16,49$ & $33,09 \pm 10,63^{\mathbf{b}}$ & $10,49 \pm 4,88^{\mathbf{b}}$ & $78,63 \pm 21,39^{\mathbf{a}}$ \\
\hline
\end{tabular}

* a: Kontrol grubuna göre anlamlı fark (p $\square 0,001)$, b: Kontrol grubuna göre anlamlı fark ( $<<0,05)$

bulunmamıştır $(\mathrm{p}>0,05)$ (Tablo 2). Kontrol grubu ile tedavi öncesi tedavi sonrası \%FEV1, FEV1 (L) düzeyleri arasındaki fark ve tedavi öncesi ile tedavi sonrası düzeyleri arasındaki fark anlamlı bulunmamıştır ( $>0,05)$ (Tablo 2). Kontrol grubu ile tedavi öncesi $\%$ FEV1/FVC düzeyleri arasında fark anlamlı bulunurken $(\mathrm{p}<0,001)$, tedavi sonrası grup arasındaki fark anlamlı bulunmamıştır $(\mathrm{p}>0,05)$. Tedavi öncesi ile tedavi sonrası grup $\% \mathrm{FEV} 1 / \mathrm{FVC}$ düzeyleri arasındaki fark anlamlı bulunmuştur $(p<0,001)$ (Tablo 2). Kontrol grubu ile tedavi öncesi \%PEF25-75\%, PEF25-75\% (L) düzeyleri arasinda fark anlamlı bulunurken $(\mathrm{p}<0,001)$, tedavi sonrası grup arasındaki fark ise anlamlı bulunmamıştır ( $\mathrm{p}>0,05)$. Tedavi öncesi ile tedavi sonrası grup \% PEF25$75 \%$, PEF25-75\% (L) düzeyleri arasındaki fark anlamlı bulunmuştur $(\mathrm{p}<0,001)$ (Tablo 2$)$. Elde edilen veriler astıml 1 hastalarda tedavinin \%FVC, \%FEV1/FVC, $\%$ PEF25-75\% ve PEF25-75\% (L) düzeyleri üzerinde etkili olduğunu ortaya koymuştur.

Tablo 2. Çalışmamızdaki tedavi öncesi ve tedavi sonrası astımlı hastalar ve kontrol grubuna ait Solunum Fonksiyon Testi (\%) FVC, FVC (L), (\%) FEV, FEV, (\%) FEV1/FVC, \%PEF\%25-75, PEF \%25-75 (L) verileri

\begin{tabular}{|c|c|c|c|c|c|c|c|}
\hline GRUPLAR & $(\%) \mathrm{FVC}$ & FVC (L) & $(\%) \mathrm{FEV}_{1}$ & $\mathrm{FEV}_{1}(\mathrm{~L})$ & $\begin{array}{c}(\%) \\
\text { FEV1/FVC }\end{array}$ & $\begin{array}{c}(\%) \\
\text { PEF\% \%-75 }\end{array}$ & $\begin{array}{l}\text { PEF \% 25-75 } \\
\text { (L) }\end{array}$ \\
\hline $\begin{array}{l}\text { Kontrol Grubu } \\
(\mathrm{n}=24)\end{array}$ & $89,46 \pm 17,57$ & $3,89 \pm 0,73$ & $93,80 \pm 19,29$ & $3,71 \pm 0,78$ & $95,37 \pm 11,34$ & $94,38 \pm 25,15$ & $3,85 \pm 1,13$ \\
\hline $\begin{array}{l}\text { Tedavi Öncesi } \\
\text { Grubu }(n=30)\end{array}$ & $77,26, \pm 18,57^{\mathbf{b}}$ & $3,55 \pm 1,07$ & $85,60 \pm 23,29$ & $3,38 \pm 0,92$ & $87,85 \pm 8,25^{a}$ & $72,03 \pm 31,37^{\mathrm{a}}$ & $2,93 \pm 1,17^{\mathrm{a}}$ \\
\hline $\begin{array}{l}\text { Tedavi Sonras } 1 \\
\text { Grubu }(\mathrm{n}=30)\end{array}$ & $83,07 \pm 24,04$ & $3,86 \pm 0,88$ & $91,86 \pm 20,57$ & $3,63 \pm 0,78$ & $95,27 \pm 7,78^{\mathrm{c}}$ & $84,80 \pm 25,79^{\mathbf{c}}$ & $3,44 \pm 0,93^{\mathbf{c}}$ \\
\hline
\end{tabular}

* a: Kontrol grubuna göre anlamlı fark $(p<0,001), b$ : Kontrol grubuna göre anlamlı fark $(p<0,05)$, c:Tedavi öncesi grubuna göre anlamlı fark $(\mathrm{p}<0,001)$.

FVC: Forced vital capacity, $\mathrm{FEV}_{1:}$ Birinci saniye zorlu ekspirasyon volümü, PEF: Tepe akım hızı

Tedavi öncesi ve tedavi sonrası astımlı hastalar ve kontrol grubuna ait toplam 84 bireyin kan örneklerindeki $\mathrm{Hb}, \mathrm{Htc}, \mathrm{WBC}$, PLT, LYM (\%) düzeylerinin aritmetik ortalama ve standart sapmaları Tablo 3'de verilmiştir. Kontrol grubu ile tedavi öncesi, tedavi sonrası, Tedavi öncesi ile tedavi sonrası $\mathrm{Hb}$, Htc, WBC, PLT, LYM düzeyleri arasındaki fark istatistiksel olarak anlamlı bulunmamıstır $(p>0,05)$ (Tablo 3$)$. Bu verilere göre astımlı hastalar üzerinde uygulanan tedavinin hastaların Hb, Htc, WBC, PLT, LYM (\%) düzeyleri üzerine etkisi olmadığı görülmektedir. Tedavi öncesi ve tedavi sonrası astımlı hastalar ve kontrol grubuna ait toplam 84 bireyin serum örneklerindeki AST, ALT, ALP, GGT aktivite düzeylerinin aritmetik ortalama ve standart sapmaları Tablo 4'de verilmiştir. Kontrol grubu ile tedavi öncesi ve tedavi sonrası serum AST, ALT, ALP, GGT aktivite düzeylerinin arasındaki ve tedavi öncesi ile tedavi sonrası serum AST, ALT, ALP, GGT aktivite düzeyleri arasındaki fark anlamlı bulunmamıştır $(\mathrm{p}>0,05)$ (Tablo $4)$. 
Tablo 3. Çalışmamızdaki tedavi öncesi ve tedavi sonrası astımlı hastalar ve kontrol grubuna ait HB, HTC, WBC, PLT. ve LYM (\%) verileri.

\begin{tabular}{|c|c|c|c|c|c|}
\hline Gruplar & $\mathrm{Hb}$ (g/dl) & Htc. (\%) & WBC $\left(10^{3} / \mu \mathrm{l}\right)$ & PLT $(k / \mu l)$ & LYM $(K / \mu \mathrm{l})$ \\
\hline $\begin{array}{l}\text { Kontrol Grubu } \\
(\mathrm{n}=24)\end{array}$ & $14,60 \pm 1,26$ & $43,54 \pm 3,80$ & $7,68 \pm 2,85$ & $263 \pm 52$ & $27,52 \pm 7,74$ \\
\hline $\begin{array}{l}\text { Tedavi Öncesi } \\
\text { Grubu }(n=30)\end{array}$ & $14,48 \pm 1,95$ & $43,15 \pm 4,92$ & $7,83 \pm 1,98$ & $257 \pm 64$ & $31,35 \pm 10,16$ \\
\hline $\begin{array}{l}\text { Tedavi Sonras1 } \\
\text { Grubu }(\mathrm{n}=30)\end{array}$ & $14,45 \pm 1,96$ & $43,02 \pm 4,93$ & $7,93 \pm 2,00$ & $267 \pm 67$ & $31,65 \pm 10,26$ \\
\hline
\end{tabular}

Hb: Hemoglobin, Htc: Hematokrit, WBC: White blood cell, PLT: Platelet, LYM: Lymphocyte, g/dl: gram/desilitre, $\mu$ l: mikrolitre

Tedavi öncesi ve tedavi sonrası astımlı hastalar ve kontrol grubuna ait toplam 84 bireyin serum örneklerindeki AST, ALT, ALP, GGT aktivite düzeylerinin aritmetik ortalama ve standart sapmaları Tablo 4'de verilmiştir. Kontrol grubu ile tedavi öncesi ve tedavi sonrasi serum AST, ALT, ALP, GGT aktivite düzeylerinin arasındaki ve tedavi öncesi ile tedavi sonrası serum AST, ALT, ALP, GGT aktivite düzeyleri arasındaki fark anlamlı bulunmamıştır $(\mathrm{p}>0,05)$ (Tablo $4)$.

Tablo 4. Çalışmamızdaki tedavi öncesi ve tedavi sonrası astımlı hastalar ve kontrol grubuna ait AST, ALT, ALP, GGT aktivite düzeyleri

\begin{tabular}{|l|c|c|c|c|}
\hline \multicolumn{1}{|c|}{ Gruplar } & AST (U/L) & ALT (U/L) & ALP (U/L) & GGT (U/L) \\
\hline $\begin{array}{l}\text { Kontrol Grubu } \\
(\mathrm{n}=24)\end{array}$ & $21,87 \pm 6,8$ & $24,79 \pm 10,15$ & $95,29 \pm 27,13$ & $23,04 \pm 10,35$ \\
\hline $\begin{array}{l}\text { Tedavi Öncesi } \\
\text { Grubu (n=30) }\end{array}$ & $22,13 \pm 7,5$ & $23,15 \pm 11,26$ & $91,80 \pm 31,32$ & $21,63 \pm 7,65$ \\
\hline $\begin{array}{l}\text { Tedavi Sonras1 } \\
\text { Grubu (n=30) }\end{array}$ & $25,40 \pm 15,57$ & $25,86 \pm 24,28$ & $96,83 \pm 30,34$ & $24,06 \pm 11,84$ \\
\hline
\end{tabular}

AST: Aspartat aminotransferaz, ALT: Alanin aminotransferaz, ALP: Alkalen fosfataz, GGT: Gama Glutamil Transferaz, U/L: ünite /litre

$\mathrm{Bu}$ verilere göre astımlı hastalar üzerinde uygulanan tedavinin hastaların AST, ALT, ALP, GGT aktivite düzeyleri üzerinde olumsuz etki göstermediği gözlenmektedir.

Asimetrik dimetil arginin (ADMA), nitrik asit sentaz (NOS) inhibitörüdür. ADMA'nın NOS aktivitesini inhibe etmesi ile L-Arginin' in hücre içine alımı engellenir. NOS'un organizmadaki fonksiyonu LArgininden nitrik oksidin sentezlenmesidir. NO vasküler homeostazın sağlanmasında önemli rol oynar, NO düzeyinin azalması ile endotel homeostaz vazokontrüksiyon lehine bozulur ve endotelyal disfonksiyon başlar, azalan NO düzeyi artmış hasara neden olur [14]. Çalışmamızda astım hastalarında tedavi öncesi ve tedavi sonrası gruplarda serum ADMA, NO ve total IgE düzeyleri, astımda rol oynayan solunum fonksiyon testleri ve hemogram düzeylerini karşılaştırdık. Astım hastalarında tedavinin hastalar üzerindeki etkileri ile ilgili yeterince çalışmaya rastlanmamıştır. Tülübaş ve ark [15] astım hastası çocuk, alerjik rinit grubunda total IgE düzeylerini sağlıklı kişilere göre yüksek tespit etmiştir. Bir başka çalışmada dikkat çekici bir şekilde, eozinofil sayımı ve total IgE'nin astımlı bireylerde anlamlı olarak yüksek olduğu bulundu. $\mathrm{Bu}$ sonuç daha önceki raporlarla uyumludur ve günümüzde eozinofili ve yüksek $\mathrm{IgE}$, atopik astımın tanımlanması için önemli biyobelirteçler olarak kabul edilmektedir [16]. Çalışmamızda tedavi öncesi ve sonrası astım grubunun toplam IgE düzeyleri kontrol grubuna göre önemli derecede yüksek bulundu. Elde ettiğimiz bu bulgunun araştırmacılar tarafından yapılan deneysel çalışmalarda elde edilen toplam IgE bulguları ile uyumlu olduğu tespit edilmiştir.

Fengyang Huang ve ark [17] astımı olan veya olmayan obez yetişkinlerde ADMA serum düzeylerinde artış olduğunu gösterildi. Normal kilolu yetişkin astımlılarda ADMA düzeylerini kontrol grubuna göre düşük seviyelerde bulunmuştur. Ancak, tüm çalışma deneklerinde ve deneklerde ADMA ile solunum fonksiyonu arasında anlamlı bir ilişki gözlenmedi.

Çalışmamızda astım grubunda ADMA düzeylerinin kontrol grubuna göre belirgin şekilde düşük olduğunu gözledik. Elde ettiğimiz bu bulgunun araştırmacılar tarafından yapılan deneysel çalışmalarda elde edilen ADMA bulguları ile uyumlu olduğu tespit edilmiştir.

Nitrik oksit (NO) yolunun astımda inflamasyonun gelişimine katkısı uzun zamandır öne sürülmüş, ancak yine de değişmiş NO homeostazının astımın enflamatuar durum özelliğindeki net etkisi henüz açıklanamamıştır. Astımlı hastalarda yapılan çalışmalarda farklı NO düzeylerinin tespiti altında yatan en önemli nedenlerden birisi de metodolojik farklılıklardır. Azalan NO düzeylerinin artmış hasara neden olabileceği çeşitli çalışmalarda gösterilmiştir $[18,19]$. Çalışmamızda tedavi öncesi ve tedavi sonrası Astım grubunun NO düzeyleri kontrol grubundan düşük olarak tespit edildi. NO oldukça labil bir molekül olup gerçek düzeylerin tespiti oldukça zor olmaktadır. 
Astım, değişken hava yolu kısıtlanmasıyla karakterizedir. Astımlı bir hastada akciğer fonksiyonu normal veya tıkanmış olabilir. Kontrol edilemeyen astım tedavi ile kontrol edilebilen astıma göre akciğer fonksiyonu ile daha ilişkilidir [20]. Azalmış FEV1 başka akciğer hastalıklarında da görülebilir fakat FEV1/FVC oranı hava yolu kısıtlanmasını gösterir [12].

Gabor ve ark. [21] yaptığı bir çalışmada iyi kontrol edilmiş astım hastalarının $\mathrm{FVC} \%, \mathrm{PEF} \%, \mathrm{PEV} 1 \%$ FEF25-75 (\%), FEV1/FVC (\%), düzeyleri ile iyi kontrol edilmemiş gruba göre düşük bulunmuştur. Çalışmamızda, astım hastalarının tedavi öncesi grupta FEV1/FVC (\%), FVC (\%), FEV1 (\%), FEF25-75 (\%) değerlerinde tedavi sonrası gruba göre düşüktü. Bu düşüş astımda solunum fonksiyonları etkilediği hastalarımızda hafif düzeyde hava akımı kısıtlanması olduğu bulunmuştur (FEV1 \%:85,60 \%). Astım hastalarının tedavi sonrası grupta Solunum Fonksiyon Testlerinden FVC ile FEV1 arasında FVC ile \%PEF25/75\% arasında önemli pozitif korelasyon bulunmuştur $(\mathrm{p}<0,001)$.

Gabor ve ark. [21] yaptığı bir çalışmada astımlı hastaların serum AST, ALT, ALP, GGT aktivite düzeylerinin kontrol grubuna göre arasındaki fark bulunmamıştır. Çalışmamızda hastalar üzerinde uygulanan tedavinin hastaların AST, ALT, ALP, GGT aktivite düzeyleri üzerinde olumsuz etki göstermediği gözlenmektedir.

\section{Sonuç}

Sonuç olarak ADMA ve NO, etkilerini birlikte gösterirler ve bu moleküller arasındaki denge hava yolu tonusunun ve fonksiyonunun s1k1 düzenlenmesine katkıda bulunmaktadır. Elde ettiğimiz veriler doğrultusunda astım tedavisinin ADMA ve NO düzeyleri üzerinde olumlu etkisi gözlenmezken, IgE, \%FVC, \%FEV1/FVC ve $\mathrm{PEF} 25 / 75 \%$ düzeyleri üzerinde olumlu etkisi saptanmıştır. Bu verilere dayanarak tedavi sonrası astım hastalarında iyileşme gözlenen parametre düzeylerinin; astım hastalarında gözlenen atağın ve tedaviye yanıtın takibi ile belirlenmesinde basit ve güvenilir olabileceği görüşünü ortaya koymaktayız.

\section{Referanslar}

1. D'Amato, G, Holgate, ST ve ark, Meteorological conditions, climate change, new emerging factors, and asthma and related allergic disorders, A statement of the World Allergy Organization. World Allergy Organisation Journal, 2015, 8(1), 25.

2. Ramratnam, SK, Bacharier, LB, Guilbert, TW, Severe Asthma in Children, Journal of Allergy and Clinical Immunology Practice, 2017, 5(4), 889-898.

3. Castillo, JR, Peters, SP, Busse, WW, Asthma Exacerbations: Pathogenesis, Prevention, and Treatment. Journal of Allergy and Clinical Immunology Practice, 2017, 5(4), 918-927.

4. Tain, YL, Hsu CN, Toxic Dimethylarginines: Asymmetric Dimethylarginine (ADMA) and Symmetric Dimethylarginine (SDMA). Toxins (Basel), 2017, 9(3), 92.

5. Roos, AB, Mori, $M$ ve ark, Elevated exhaled nitric oxide in allergenprovoked asthma is associated with airway epithelial iNOS. PLoS One. 2014, 9(2): e90018.

6. Lau, E.M, Morgan, PE ve ark, Asymmetric dimethylarginine and asthma: results from the Childhood Asthma Prevention Study. European Respiratory Journal, 2013, 41(5), 1234-7.

7. Scott, JA, North, ML ve ark, Asymmetric dimethylarginine is increased in asthma, American Journal of Respiratory and Critical Care Medicine, 2011, 184(7), 779-85.
8. Carraro, S, Giordano ve ark, Asymmetric dimethylarginine in exhaled breath condensate and serum of children with asthma, Chest, 2013 144(2), 405-410.

9. Holguin, F, Comhair, SA ve ark, An association between Larginine/asymmetric dimethyl arginine balance, obesity, and the age of asthma onset phenotype. American Journal of Respiratory and Critical Care Medicine, 2013, 187(2), 153-9.

10. Boulet, L.P, Gauvreau, G ve ark, Clinical Investigative Collaboration, Canadian Network of Centers of Excellence AllerGen, The allergen bronchoprovocation model: an important tool for the investigation of new asthma anti-inflammatory therapies, Allergy, 2007, 62(10):1101-10

11. Pizzichini, E, Pizzichini, MM ve ark, Indices of airway inflammation in induced sputum: reproducibility and validity of cell and fluidphase measurements. American Journal of Respiratory and Critical Care Medicine, 1996, 154(2 Pt 1), 308-17.

12. Global Strategy For Asthma Management and Prevention (GINA). 2017

13. Miller, MR, Hankinson, J, Brusasco, V, Burgos, F, Casaburi, R, Coates, A, Crapo, R, Enright, P, Van der Grinten, C.P.M, Gustafsson, P, Jensen, R, Johnson, D.C, MacIntyre, N, McKay, R, Navajas, D, Pedersen, O.F, Pellegrino, R, Viegi, G, Wanger, J, Standardization of spirometry, European Respiratory Journal, 2005, 26, 319-338.

14. Buğdayc1, G, Serin, E, Asimetrik Dimetilarginin (ADMA), Düzce Medical Journal, 2005, 2, 36-41.

15. Tülübas, F, Gürel, A, Donma, M.M, Nalbantoğlu, B, Topçu, B, Mut, D.Z, Astım ve alerjik rinitli çocuklarda total IgE, C-reaktif protein ve kan sayım parametrelerinin değerlendirilmesi. Dicle Medical Journal, 2013, 40(1), 57-61.

16. Berry, A, Busse, WW, Biomarkers in asthmatic patients: Has their time come to direct treatment? Journal of Allergy and Clinical Immunology, 2016, 137, 1317-1324.

17. Huang, F, Del-Río-Navarro, B.E, Torres-Alcántara, S, PérezOntiveros, J.A, Ruiz-Bedolla, E, Saucedo-Ramírez, O.J, Villafaña, S, Sánchez Muñoz, F, Bravo, G, Hong, E, Adipokines, asymmetrical dimethylarginine, and pulmonary function in adolescents with asthma and obesity. Journal of Asthma, 2017, 54(2), 153-161.

18. Ashutosh K. Nitric oxide and asthma: a review, Current Opinion in Pulmonary Medicine, 2000, 6(1), 21-5.

19. Essat, M, Harnan ve ark, Fractional exhaled nitric oxide for the management of asthma in adults: a systematic review. European Respiratory Journal, 2016, 47(3), 751-68

20. Reddel, H, Ware, S ve ark, Differences between asthma exacerbations and poor asthma control. Lancet 30, 353(9150), 364-9.

21. Tajti, G, Papp, C ve ark, Positive correlation of airway resistance and serum asymmetric dimethylarginine (ADMA) in bronchial asthma patients lacking evidence for systemic inflammation, Allergy, Asthma \& Clinical Immunology, 2018,14, 2

http://edergi.cbu.edu.tr/ojs/index.php/cbusbed isimli yazarın CBU-SBED başlıklı eseri bu Creative Commons Alıntı-Gayriticari4.0 Uluslararası Lisansı ile lisanslanmıştır.

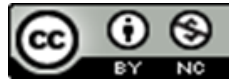

